\title{
IMPLEMENTASI MODEL PEMBELAJARAN TEAM TEACHING UNTUK MENINGKATKAN PRESTASI BELAJAR SISWA BIDANG STUDI MATEMATIKA KELAS VIII MTS. NURUL HUDA GENTENG TAHUN AJARAN 2017-2018
}

\author{
Nawal Ika Susanti \\ Institut Agama Islam Darussalam Blokagung Banyuwangi \\ Email:nika.girl22@gmail.com
}

\begin{abstract}
This research is a Class Action Research which aims to improve students' mathematics learning outcomes through the Teaching Teaching Learning model in class VIII MTs. Nurul Huda material Triangle. This research was conducted in 2 cycles, namely from each cycle consisting of 5 meetings and the last meeting was used for evaluation. During the implementation of the cycle, the team teaching learning model can be said to be quite successful because it can increase student activity and learning outcomes. An increase in activity and learning outcomes from the implementation of learning cycle I to cycle II is $6.11 \%$.. So it can be concluded that student activities fall into the active category. As for student learning outcomes in the first cycle of $77.27 \%$ and $90.9 \%$ in cycle II, so that student learning outcomes experienced an increase of $13.63 \%$. This shows that team teaching learning models can improve student activity and student learning outcomes. Based on the analysis of the results of tests I and II, one of the obstacles faced by students at the time of testing was the lack of students' understanding of the count operation on the triangle. Another factor is the inaccuracy of students in doing the tests given.
\end{abstract}

Keywords: Team Teaching Learning Model, Classroom Action Research, Triangle.

\begin{abstract}
Abstrak
Penelitian ini merupakan Penelitian Tindakan Kelas yang bertujuan untuk meningkatkan hasil belajar matematika siswa melalui model Pembelajaran Team Teaching di kelas VIII MTs. Nurul Huda materi Segitiga. Penelitian ini dilakukan dalam 2 siklus, yaitu dari setiap siklus terdiri dari 5 kali pertemuan dan pada pertemuan terakhir digunakan untuk evaluasi. Selama pelaksanaan siklus dilaksanakan, model pembelajaran team teaching dapat dikatakan cukup berhasil karena dapat meningkatkan aktivitas dan hasil belajar siswa. Terjadi peningkatan aktivitas dan hasil belajar dari pelaksanaan pembelajaran siklus I ke siklus II sebesar 6,11\%. Jadi dapat disimpulkan bahwa aktivitas siswa termasuk dalam kategori aktif. Sedangkan untuk hasil belajar siswa pada siklus I sebesar 77,27\% dan 90,9\% pada siklus II, sehingga hasil belajar siswa mengalami peningkatan sebesar 13,63\%. Hal ini menunjukkan bahwa model pembelajaran team teaching dapat meningkatkan aktivitas siswa serta hasil belajar siswa. Berdasarkan analisa hasil tes I dan II, salah satu kendala yang dihadapi siswa pada saat mengerjakan tes adalah kurangnya pemahaman siswa terhadap operasi hitung pada segitiga. Faktor lainnya adalah ketidaktelitian siswa dalam mengerjakan tes yang diberikan.
\end{abstract}

Kata Kunci : Model Pembelajaran Team Teaching, Penelitian Tindakan Kelas, Segitiga. 


\section{A. Pendahuluan}

Salah satu hakikat matematika yaitu matematika sebagai ratunya ilmu sehingga matematika memiliki peranan penting terhadap perkembangan IPTEK yang semakin berkembang pesat. Oleh karena itu, perkembangan matematika mendapat perhatian khusus bagi pemerintah untuk dapat meningkatkan kualitas siswa pada bidang matematika. Salah satu upaya yang dilakukan oleh pemerintah adalah memberikan bobot kelulusan pada Ujian Akhir Nasional yaitu nilai UAN dari pemerintah mempunyai bobot $40 \%$ sedangkan sisanya $60 \%$ berasal dari nilai sekolah/madrasah. Kebijakan ini diterapkan karena banyaknya angka ketidaklulusan siswa saat mengikuti Ujian Akhir Nasional terutama pada bidang studi matematika. Selain itu, perubahan kurikulum dari kurikulum KBK ke kurikulum 13 juga menjadi salah satu upaya pemerintah dalam meningkatkan kualitas pendidikan di Indonesia. Kurikulum 13 yang diterapkan di sekolah menjadikan pembelajaran terpusat pada siswa, sehingga pendidik disini berperan sebagai fasilitator dalam pembelajaran. Tidak berbeda jauh dalam pembelajaran matematika di sekolah, guru matematika harus pandai menciptakan lingkungan kelas yang efektif dalam proses kegiatan belajar mengajar. Berbagai model pembelajaran diterapkan dalam proses Kegiatan belajar mengajar di kelas dengan tujuan untuk dapat meningkatkan hasil belajar siswa. Kekreatifan guru dalam menentukan model dan metode pembelajaran yang sesuai dengan materi yang diajarkan sangat penting dilakukuan oleh guru.

Berdasarkan observasi sementara yang dilakukan di MTs. Nurul Huda pada salah satu bidang pelajaran yaitu pelajaran matematika, ditemukan beberapa hal yang menarik untuk dikaji diantaranya model pembelajaran yang masih cenderung berpusat pada guru padahal dalam kurikulum 13 pembelajaran seharusnya berpusat pada siswa, keaktifan siswa dalam kegiatan belajar mengajar di kelas masih kurang, dan juga belum terpenuhinya nilai kriteria ketuntasan minimal pelajaran matematika yaitu 70 sehingga menyebabkan hasil belajar siswa belum maksimal. Oleh karena itu untuk mengatasi problematika yang ditemukan di MTs. Nurul Huda, maka peneliti mencoba menerapkan model pembelajaran yang melibatkan guru matematika lebih dari satu guru di saat kegiatan belajar 
mengajar berlangsung untuk mengontrol keaktifan siswa di dalam kelasdengan pembagian peran dan tanggung jawab secara jelas dan seimbang. Model pembelajaran ini lebih dikenal dengan istilah model pembelajaran team teaching (mengajar beregu). Sehingga kebutuhan siswa akan bimbingan guru pada saat proses pembelajaran dapat terpenuhi dan tujuan pembelajaran dapat tercapai. Selanjutnya hal ini akan berpengaruh terhadap hasil belajar siswa.

Tujuan dalam penelitian ini adalah untuk mengetahui bagaimanakah proses pembelajaran di dalam kelas dengan menggunakan model pembelajaran team teaching, bagaimanakah aktivitas siswa di dalam kelas dan bagaimanakah hasil belajar siswa dengan menggunankan model pembelajaran team teaching.

\section{B. Landasan Teori}

1. Model Pembelajaran Team Teaching

Team teaching merupakan model dalam pembelajaran yang pertama kali dikembangkan di Jepang. Pada dasarnya tujuan pembelajaran team teaching diterapkan sebagai upaya untuk meningkatkan hasil belajar siswa. Team teachingadalah suatu model mengajar yang dilakukan oleh dua orang guru atau lebih, mengajar sejumlah anak yang mempunyai perbedaanperbedaan baik minat, kemampuan maupun tingkat kelasnya (Engkoswara, 1988:64). Model ini diterapkan dengan berorientasi pada siswa, sedangkan guru dapat memantau sampai sejauh mana materi dapat dipahami siswa. Sehingga dapat membantu setiap siswa dalam menghadapi kesulitan belajar. Engkoswara (1988:67) juga menjelaskan beberapa manfaat dari team teaching, yakni: (1) persiapan dan perencanaan mengajar lebih lengkap bila dikerjakan oleh tim yang lengkap dan penuh tanggungjawab, (2) bila salah seorangguru tidak dapat mengajar tidak perlu ada pembebasan kelas, guru yang lainnya dapat melanjutkan pelajaran menurut rencana yang telah diterapkan bersama, (3) guru-guru saling membantu bila di antara mereka (anggota) ada yang kurang memahami salah satu mata pelajaran, (4) anakanak memperoleh sumber dan bahan pelajaran dari beberapa orang yang berbeda kecakapannya, (5) anak memilih dan melakukan tugas sesuai dengan 
minat dan kecakapan belajar masing-masing, (6) team teaching memberi kesempatan kepada orang-orang yang mempunyai kecakapan khusus yang tidak mempunyai profesi guru, tetapi mau membantu guru mengajar. Pelaksanaan team teaching dapat dilakukan melalui beberapa pola antara lain:

a. Beberapa guru mengajarkan mata pelajaran sama, di kelas berbeda-beda. Dalam proses perencanaan, materi, bahan ajar, atau hand out dapat disusun bersama-sama, walaupun penyajian dan evaluasi dilakukan masingmasing.

b. Setiap guru melakukan perencanaan, menentukan materi, penyajian, dan evaluasi masing-masing, tetapi pada saat evaluasi dilaksanakan secara bersama-sama.

c. Satu mata pelajaran dapat diajarkan oleh lebih dari seorang guru secara bersama-sama, mulai perencanaan, pelaksanaan dan penilaian. Dalam pelaksanaan pembelajaran, seorang guru sebagai penyaji atau menyampaikan informasi, guru yang lain membantu menyiapkan media pembelajaran, membimbing diskusi kelompok atau membimbing latihan individual. Anggota team teaching dapat pula secara bergantian menyajikan topik atau materi. Diskusi dan tanya jawab dibimbing secara bersama dan saling melengkapi jawaban dari anggota tim (Awie. 2010).

Jika dalam pengajaran tunggal seorang guru harus menguasai kelas seorang diri, maka dalam team teaching mulai dari awal hingga akhir pembelajaran kelas dikelolah oleh seluruh anggota tim pengajar. Sehingga memungkinkan proses pengajaran menjadi lebih baik karena perencanaan pembelajaran dilakukan secara bersama-sama. Kendala-kendala yang ditemui pada saat pelaksanaan pembelajaran dapat didiskusikan bersama untuk selanjutnya mencari solusi dari permasalahan tersebut. Bagaimanapun juga dua kepala atau lebih akan lebih baik dalam pengambilan keputusan karena setiap anggota tim saling melengkapi kekurangan rekan timnya. Dalam team teaching dibutuhkan tingkat kerja sama yang tinggi sesama anggota tim agar setiap anggota dapat menjalankan tugas masing-masing danproses 
pembelajaran dapat terlaksana sesuai dengan perencanaan pembelajaran yang telah dibuat bersama.

Untuk mendapatkan hasil yang baik dari implementasi metode team teaching dalam pembelajaran matematika ini, maka ada beberapa langkah yang harus disesuaikan bagi guru yang bergabung dalam regu mengajar tersebut. Langkah awal dimulai dengan menyusun perencanaan pembelajaran secara bersama, sehingga apa yang tercantum dalam isi perencanaan itu dan bagaimana sistem evaluasi yang akan dilakukan dapat dipahami oleh setiap guru yang tergabung dalam team teaching. Langkah yang kedua yaitu menyusun metode pembelajaran secara bersama, hal ini diharapkan bahwa setiap guru dapat mengetahui alur proses pembelajaran tujuan pembelajarandan arah pembelajaran. Langkah ketiga yang dilakukan dalam proses pembelajaran team teaching adalah membedah dan mendiskusikan materi dan isi pembelajaran yang akan diberikan kepada siswa, hal ini bertujuan agar setiap guru dapat saling melengkapi kekurangan pengetahuan yang ada pada diri masing-masing. Selain itu juga, setiap guru dapat memprediksi berbagai kemungkinan kesulitan yang dihadapi siswa dalam proses pembelajaran matematika di kelas. Dan langkah yang terakhir adalah membagi peran dantanggung jawab masing-masing guru yang tergabung dalam team teaching, agar dalam prosespembelajaran di dalam kelas, masingmasing mengetahui peran dan tugasnya dan dapat saling membantu dalam melaksanakan pembelajaran. Dan apabila telah selesai dalam melaksanakan pembelajaran, setiap guru dapat duduk bersama untuk mengevaluasi pelaksanaanpembelajaran, sehingga dapat merumuskan perbaikan-perbaikan untuk pembelajaran berikutnya (Wardani. 2001).

2. Aktivitas Belajar Siswa

Seseorang dikatakan belajar apabila mengalami perubahan, maupun kognitifnya. Belajar akan lebih bermakna jika anak "mengalami” apa yang dipelajarinya, bukan “mengetahui”"nya ( Riyanto. 2008:109). Arikuto (2008, 3) menjelaskan bahwa ciri anak dalam keadaan belajar adalah otaknya aktif 
berpikir, mencerna bahan yang dipelajari. Dierich dalam Hamalik (2009:172173), membagi kegiatan belajar menjadi delapan kelompok, yakni:

a. Kegiatan-kegiatan visual

Membaca, melihat gambar-gambar, mengamati, eksperimen, demonstrasi, pameran, dan mengamati orang lain bekerja atau bermain.

b. Kegiatan-kegiatan lisan (oral)

Mengemukakan suatu fakta atau prinsip, menghubungkan suatu kejadian, mengajukan pertanyaan, memberi saran, mengemukakan pendapat, wawancara, diskusi dan interupsi.

c. Kegiatan-kegiatan mendengarkan.

Mendengarkan penyajian bahan, mendengarkan percakapan atau diskusi kelompok, mendengarkan suatu permainan, mendengarkan radio.

d. Kegiatan-kegiatan menulis

Menulis cerita, menulis laporan, memeriksa karangan, bahan-bahan kopi, membuat rangkuman, mengerjakan tes, dan mengisi angket.

e. Kegiatan-kegiatan menggambar

Menggambar, membuat grafik, chart, diagram peta, dan pola.

f. Kegiatan-kegiatan metrik

Melakukan percobaan, memilih alat-alat, melaksanakan pameran, membuat model, menyelenggarakan permainan, menari, dan berkebun.

g. Kegiatan-kegiatan mental

Merenungkan, mengingat, memecahkan masalah, menganalisis, faktorfaktor, melihat, hubungan-hubungan, dan membuat keputusan.

h. Kegiatan-kegiatan emosional

Minat, membedakan, berani, tenang dan lain-lain. Kegiatan-kegiatan dalam kelompok ini terdapat dalam semua jenis kegiatan dan overlap satu sama lain.

Hamalik (2009:171) juga menjelaskan bahwa pengajaran yang efektif adalah pengajaran yang menyediakan kesempatan belajar sendiri atau melakukan aktifitas sendiri. 


\section{Metode Penelitian}

1. Jenis Penelitian

Jenis penelitian yang dilakukan merupakan penelitian tindakan kelas. PTK adalah suatu pendekatan untuk meningkatkan pendidikan dengan melakukan perubahan kearah perbaikan terhadap hasil pendidikan dan pembelajaran (Arikunto. 2008:105 ). Model yang digunakan dalam penelitian ini adalah model Hopkins yang berbentuk spiral. Dimana tindakan diawali dengan perencanaan tindakan (planing), penerapan tindakan (action), mengobservasi dan mengevaluasi (observation and evaluatioan) dan melakukan refleksi (reflecting). Berdasarkan model skema penelitian tindakan Hopkins tersebut maka dikembangkan desain penelitian seperti yang tersaji dalam Gambar 1.

\section{Gambar 1. Skema Penelitian}

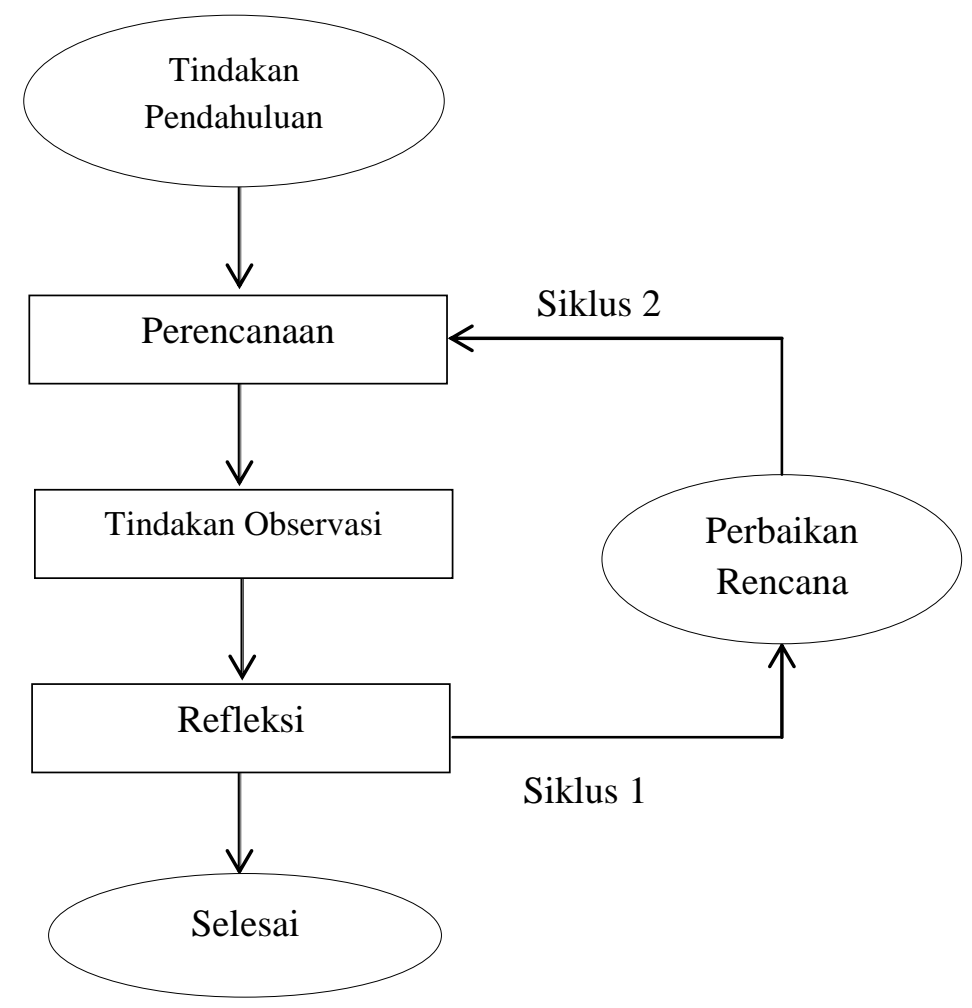

Sumber: Data Primer diolah. 2018 
2. Subyek Penelitian

Subyek dalam penelitian ini adalah siswa kelas VIII MTs. Nurul Huda sejumlah 22 siswa, yang terdiri dari 12 siswa laki-laki dan 10 siswa perempuan dengan tingkat akademis yang berbeda-beda.

3. Instrumen Penelitian

Instrumen yang digunakan adalah soal tes berupa evaluasi pertemuan akhir setiap siklus yang disusun untuk mengetahui sejauh mana peningkatan hasil belajar siswadengan menggunakan model pembelajaran team teaching.

4. Metode Pengumpulan Data

Metode pengumpulan data yang digunakan antara lain:

a. Metode tes

Pada penelitian ini tes yang diberikan berupa tes obyektif dan subyektif. Pembagian jumlah soal tes sendiri terdiri dari 10 soal obyektif dan 5 soal subyektif. Pembuatan tes berdasarkan pada kisi-kisi tes yang disesuaikan dengan indikator yang ingin dicapai dalam pembelajaran. Hasil belajar siswa dalam penelitian ini diperoleh dari hasil tes siklus I dan siklus II.

b. Metode Wawancara

Pada penelitian ini, wawancara dilakukan pada guru bidang studi Matematika dan siswa kelas VIII yang bertindak sebagai subyek dalam penelitian. Adapun pelaksanaan wawancara dilakukan menjadi dua tahap, yakni wawancara sebelum pelaksanaan penelitian dengan tujuan untuk mengetahui masalah pembelajaran yang dialami subyek penelitian dan wawancara setelah dilakukan penelitian dengan tujuan untuk mendapatkan informasi tentang pembelajaran Matematika dengan model team teaching.

c. Metode Observasi

Pada penelitian ini metode observasi dilakukan pada saat berlangsungnya kegiatan belajar mengajar dengan bantuan tiga orang observer. Observasi dilakukan dengan cara mengadakan pengamatan langsung terhadap gejalagejala subyek yang diteliti, yakni berupa aktifitas siswa dan guru. Tujuan observasi keaktifan siswa untuk mengetahui interaksi dan keikutsertaan 
siswa dalam kegiatan belajar mengajar di kelas dengan model pembelajaran team teaching.

\section{d. Metode Dokumentasi}

Metode ini dilakukan untuk memperoleh daftar nama siswa yang termasuk dalam subyek penelitian.

5. Metode Analisis Data

Analisis data kuantitatif dan kualitatif dimaksudkan untuk mengolah data atau informasi yang diteliti. Pada penelitian ini, data yang akan dianalisis adalah sebagai berikut :

a. Hasil belajar

Nilai dari hasil belajar merupakan data kuantitatif. Analisis persentase ketuntasan belajar siswa dilakukan dengan menggunakan rumus:

Kriteria ketuntasan belajar adalah sebagai berikut:

1) Daya serap perorangan, siswa dinyatakan tuntas apabila hasil yang diperoleh $\geq 70$ dari skor maksimal 100

2) Daya serap klasikal, suatu kelas dinyatakan tuntas apabila $75 \%$ siswa dari jumlah seluruh siswa telah mencapai hasil $\geq 70$. (Djamarah dan Zain. 2002: 122)

b. Observasi dan wawancara

Hasil dari observasi berupa data kualitatif, yakni deskripsi kegiatan dan aktifitas pada penerapan model pembelajaran team teaching., analisis aktifitas siswa dilakukan dengan mengunakan rumus sebagai berikut:

Kriteria keaktifan siswa dinyatakan sebagai berikut:

Tabel 1. Kriteria Aktifitas Siswa

\begin{tabular}{|c|c|}
\hline Persentase & Kategori \\
\hline $\mathrm{P} \geq 90 \%$ & Sangat Aktif \\
\hline $80 \% \leq \mathrm{P}<90 \%$ & Aktif \\
\hline $65 \% \leq \mathrm{P}<80 \%$ & Cukup Aktif \\
\hline $50 \% \leq \mathrm{P}<65 \%$ & Kurang Aktif \\
\hline $\mathrm{P}<50 \%$ & Tidak Aktif \\
\hline
\end{tabular}

Sumber: Depdiknas dalam Asih. 2002:20

Wawancara dilakukan dengan tujuan untuk mengetahui tanggapan dan pengaruh pembelajaran model team teaching terhadap hasil belajar siswa. Selanjutnya data kualitatif yang diperoleh akan dianalisis secara deskriptif. 


\section{Hasil}

Pelaksanaan pembelajaran model team teaching terdiri dari perencanaan, pelaksanaan dan penilaian dilakukan secara bersama-sama. Berdasarkan kesepakatan bersama, maka kelas dibagi menjadi lima kelompok dengan jumlah siswa 4-5 anggota. Pembelajaran dilakukan oleh dua anggota tim pengajar yang terdiri dari peneliti dan guru matematika di MTs. Nurul Huda.

1. Pelaksanaan Siklus 1

a. Perencanaan

Ada beberapa kegiatan yang dilakukan peneliti pada tahap ini, yaitu : 1) Menyusun silabus matematika semester genap Tahun Ajaran 2017/2018. 2) Menyusun Rencana Pelaksanaan Pembelajaran (RPP) yang disesuaikan dengan dengan silabus 3) Menyusun LKS I untuk pertemuan pertama, LKS II untuk pertemuan kedua, LKS III untuk pertemuan ketiga, 4) Menyusun soal tes I beserta hasil jawabannya5) Menyiapkan media yang digunakan dalam proses pembelajaran.6) Menyusun format pedoman observasiPenyusunan silabus, rencana pembelajaran, LKS dan soal tes beserta jawabannya dilakukan secara bersama-sama tetapi didominasi oleh guru A. Sedangkan guru B bertugas menyiapkan media pembelajaran.

b. Pelaksanaan

Sesuai dengan rencana yang telah disepakati bersama dengan guru bidang studi matematika, maka penelitian dilakukan pada kelas VIII dengan materi Sub Pokok Bahasan Segitiga yang berlangsung selama 4 kali pertemuan yang terdiri dari 3 x 40 menit untuk dua kali pertemuan dan 2 x 40 menit untuk dua kali pertemuan. Pertemuan pertama hingga pertemuan ketujuh dilaksanakan pembelajaran pertama Sub Pokok Segitiga. Materi yang dipelajari pada siklus I ini mengenai luas dan keliling segitiga, perbandingan segitiga istimewa dan teorema phytagoras, penerapan segitiga dalam kehidupan sehari hari. Adapun tehnik pembagian tugas tim pengajar digambarkan sebagai berikut:

Sebelum pembelajaran dimulai, guru A (peneliti) terlebih dahulu menyampaikan tujuan dari pembelajaran sekaligus menginformasikan bahwa 
pembelajaran materi segitiga akan dilakukan empat kali pertemuan yang ditambah satu kali pertemuan untuk tes. Selanjutnya guru A menjelaskan kepada siswa tentang metode pembelajaran yang akan digunakan. Guna memastikan bahwa siswa benar-benar paham terhadap metode yang dilakukan, maka guru A memberi kesempatan pada siswa yang masih kurang jelas untuk bertanya mengenai metode pembelajaran yang sudah dijelaskan guru. Sehingga diharapkan proses pembelajaran dapat berjalan dengan lancar. Sementara guru A menjelaskan metode pembelajaran di depan kelas, maka guru B (rekan) menyiapkan media dan LKS I yang digunakan dalam pembelajaran. Observator mengamati dan melakukan observasi selama proses pembelajaran berlangsung.

\section{Gambar 2. Skema Pembagian Tugas Tim Pengajar Pertemuan I Siklus I}

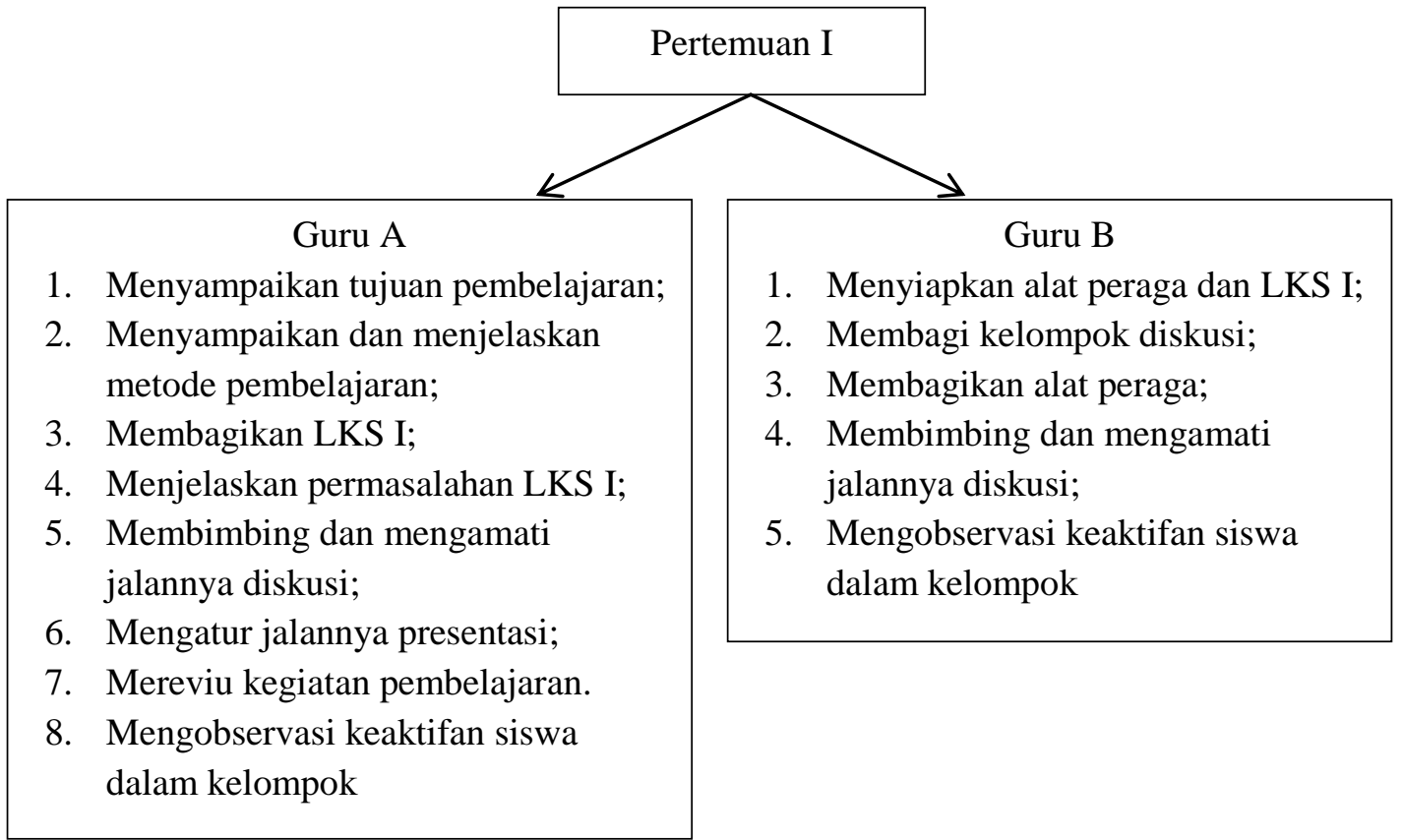

Sumber: Data Primer di olah. 2018

Masuk pada kegiatan inti pembelajaran, guru B membagi kelas menjadi beberapa kelompok sesuai dengan yang sudah dibuat sebelumnya dengan tim dan meminta siswa untuk duduk sesuai dengan kelompoknya masing-masing. Setelah tim memastikan bahwa siswa sudah duduk sesuai dengan kelompoknya, guru A bertugas membagikan LKS pada tiap siswa sementara 
guru B membagikan alat peraga pada tiap kelompok yang berupa alat peraga sederhana yang terbuat dari kardus dan kertas untuk mengetahui bagaimana mencari luas dan keliling dari segitiga. Setelah semua selesai dibagikan, guru A menjelaskan sekilas tentang permasalahan dalam LKS. Dan memberi perintah siswa untuk mengerjakan LKS. Selanjutnya siswa berdiskusi dengan kelompok untuk mengerjakan permasalahan dalam LKS sesuai waktu yang telah ditentukan. Selama proses pembelajaran, guru A dan guru B (tim pengajar) berkeliling untuk mengamati jalannya diskusi dan membimbing kelompok yang mengalami kesulitan pada saat berdiskusi.

Setelah diskusi dalam kelompok selesai, maka kegiatan selanjutnya adalah presentasi hasil diskusi di depan kelas. Secara acak, tim memilih salah seorang siswa untuk presentasi. Sedangkan siswa yang lainnya dimintauntuk menambahi atau memberi komentar. Adapun siswa yang terpilih untuk presentasi adalah Anisa Lailatul Fitriyah dan Novia Putri Ramadhani.Selanjutnya diakhir pembelajaran guru A mengarahkan siswa untuk membuat kesimpulan dari materi yang telah dipelajari. Pada pertemuan II dan III, tehnik pembagian tugas tim pengajar digambarkan sebagai berikut:

\section{Gambar 3. Skema Pembagian Tugas Tim Pengajar Pertemuan II dan III Siklus I}

\begin{tabular}{|l|l|l|}
\multicolumn{1}{|c|}{ Guru A } &
\end{tabular}

Sumber: Data Primer di olah. 2018 
Kegiatan Belajar Mengajar yang dilakukan pada pertemuan II dan III tidak jauh berbeda dengan pertemuan I. Pembagian tugas dari tim mengajar hanya bertukar tugas saja ketika kegiatan belajar mengajar berlangsung. Pembagian kelompok tetap mengikuti pembagian awal. LKS II dan alat peraga yang telah disiapkan oleh guru A dibagikan di setiap kelompok. Di akhir diskusi kelompok, maka di pilih perwakilan dari kelompok untuk mempresentasikan hasil diskusi. Siswa yang terpilih untuk mempresentasikan hasil diskusinya adalah Muh. Ali Hasani dan Dina Umami. Setelah presentasi selesai, guru mempertegas hasil presentasi karena masih terdapat kesalahan pemahaman dalam memahami teorema phytagoras. Selanjutnya dengan bimbingan guru B, siswa diminta untuk membuat kesimpulan.

Kegiatan utama pada pertemuan keempat adalah tanya jawab, dengan tehnik pembagian tugas pengajar sebagai berikut:

\section{Gambar 4. Skema Pembagian Tugas Tim Pengajar Pertemuan IV Siklus I}

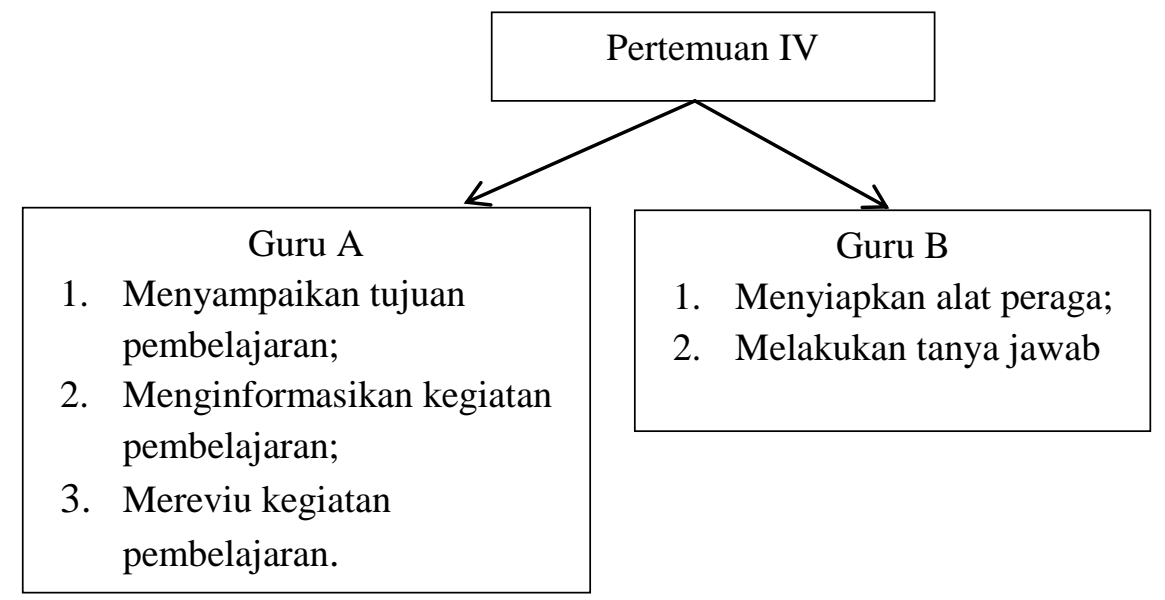

Sumber: Data Primer di olah. 2018

Berdasarkan skema, guru A mengucapkan salam dan menyampaikan tujuan pembelajaran sedangkan guru B menyiapkan media yang dibutuhkan. Siswa tidak dikondisikan untuk duduk berdasarkan kelompoknya. Tanya jawab dilakukan secara lisan dan tertulis dibawah kendali tim pengajar secara bergantian. Selanjutnya diakhir pembelajaran, guru A membimbing siswa membuat kesimpulan terhadap pembelajaran yang telah dilakukan dan mengingatkan kembali bahwa pertemuan selanjutnya akan diadakan tes. 
Sehingga siswa diminta untuk mempelajari kembali semua materi yang sudah dipelajari. Walau tidak ada aktivitas diskusi, tetapi observer tetap melakukan observasi terhadap aktivitas siswa.

Tes dilakukan pada pertemuan kelima, tempat duduk siswa tidak dikondisikan sesuai dengan kelompok Asal maupun kelompok Ahli tetapi sesuai dengan tempat duduk masing-masing. Tes dilakukan selama 80 menit dengan jumlah 10 soal obyektif dan 5 soal essay.

c. Penilaian

1) Hasil Aktifitas Siswa Dalam Kelas Siklus I

Berdasarkan hasil observasi yang dilakukan oleh tim pengajar selama kegiatan belajar mengajar dikelas maka dapat dilihat pada Tabel 2.

Tabel 2. Observasi Keaktifan Siswa Siklus I

\begin{tabular}{|c|l|c|}
\hline No & \multicolumn{1}{|c|}{ Aspek Pengamatan } & Persentase \\
\hline 1 & Kemampuan siswa dalam diskusi kelompok & 82,05 \\
\hline 2 & Kemampuan siswa dalam mengemukakan pendapat & 74,36 \\
\hline 3 & $\begin{array}{l}\text { Kemampuan siswa dalam memperhatikan pemdapat } \\
\text { teman }\end{array}$ & 83,33 \\
\hline 4 & Kemampuan siswa dalam bertanya & 75,64 \\
\hline 5 & $\begin{array}{l}\text { Kemampuan siswa dalam presentasi hasil diskusi di } \\
\text { dalam kelompok }\end{array}$ & 73,08 \\
\hline 6 & $\begin{array}{l}\text { Kemampuan siswa dalam memperhatikan } \\
\text { penjelasan teman }\end{array}$ & 100 \\
\hline 7 & Kemampuan siswa dalam menyelesaikan LKS & 82,05 \\
\hline 8 & $\begin{array}{l}\text { Kemampuan siswa dalam mempresentasikan hasil } \\
\text { diskusi di depan kelas }\end{array}$ & \\
\hline
\end{tabular}

Sumber: Data Primer di olah. 2018

Berdasarkan analisis hasil observasi keterampilan siswa dalam mempresentasikan hasil diskusi merupakan aktivitas dengan prosentase paling rendah diantara aktivitas lainnya. Siswa cenderung merasa kesulitan pada saat menjelaskan materi kepada anggota kelompoknya. Selain itu siswa lebih aktif dalam bertanya daripada mengemukakan perdapat. Walaupun siswa masih tampak belum terbiasa dengan metode pembelajaran yang dilakukan. namun secara menyeluruh, siswa tampak antusias dalam mengikuti proses pembelajaran dan telah menyelesaikan LKS yang diberikan dengan baik. 
2) Analisa Hasil belajar

Berdasarkan hasil tes yang diperoleh dari 22 siswa, 5 siswa dinyatakan tidak tuntas dan 17 sisanya telah mencapai ketuntasan belajar berdasarkan SKM yang ditetapkan sekolah yakni 70. Prosentase ketuntasan pembelajaran mencapai $77,27 \%$. Sehingga dapat dikatakan secara klasikal pembelajaran pada siklus I telah mencapai ketuntasan belajar.

d. Refleksi

Refleksi dilakukan dengan cara menganalisis, memahami dan menyimpulkan hasil pembelajaran mulai dari pelaksanaan tindakan hingga tes. Meskipun kelas telah mencapai ketuntasan sebesar $77,27 \%$, tetapi perlu dilakukan perbaikan-perbaikan agar hasil belajar siswa pada siklus II meningkat. Pada saat pembelajaran berlangsung, diketahui bahwa terdapat salah seorang siswa merasa kesulitan berdiskusi dengan kelompoknya, hal ini disebabkan hubungan sosial dengan teman satu kelas kurang begitu baik yang menyebabkan diskusi menjadi terhambat. Untuk mengatasi hal tersebut, tim pengajar memberikan arahan dan dorongan terhadap siswa tersebut beserta anggota kelompoknya agar dapat berdiskusi dengan baik. Selanjutnya pengawasan lebih maksimal diberikan agar diskusi dapat terlaksana sesuai dengan yang diharapkan.

Secara umum seluruh siswa sudah aktif dalam pembelajaran, terbukti dari prosentase aktivitas siswa yang mencapai 82,37\%. Sehingga dapat dikatakan bahwa aktivitas siswa pada pembelajaran siklus I termasuk kategori aktif. Dengan jumlah siswa sebanyak 22, tim pengajar memiliki banyak kesempatan untuk memantau jalannya diskusi. Sehingga siswa yang masih tampak bercanda sendiri pada saat diskusi dapat segera diatasi.

2. Pelaksanaan Siklus II

Dalam pelaksanaan siklus 1 masih ada beberapa siswa yang tidak tuntas meskipun kelas telah mencapai ketuntasan sebesar 77,27\% namun masih harus ada beberapa perbaikan yang dilakukan oleh tim pengajar untuk lebih meningkatkan hasil belajar siswa. Oleh karena itu pelaksanaan siklus II 
diperlukan dalam memperbaiki hal tersebut. Dalam pelaksanaan siklus II tidak jauh berbeda dengan pelaksanaan siklus I. Pembagian tugas mengajar guru dalam tim pengajar juga masih sama dengan pembagian tugas guru pada siklus I. Dalam hal ini yang membedakan antara siklus I dan siklus II adalah dalam proses aktifitas siswa di dalam kelas. Dari hasil siklus I, guru sudah dapat melihat bagaimanakah aktifitas siswa dalam kegiatan belajar mengajar di kelas. Pada siklus II tim pengajar lebih memperhatikan siswa yang masih kurang dalam beraktifitas di dalam kelas tanpa mengurangi perhatian pada siswa yang dirasa cukup memiliki aktifitas di dalam kelas. Selain proses aktifitas di dalam kelas, pembuatan LKS IV, V dan VI juga berbeda dalam bentuk uraian soal.

a. Perencanaan

Dalam tahap perencanaan di siklus II ini kegiatan yang dilakukan tim pengajar masih sama diantaranya 1) membuat silabus dan RPP, 2) membuat LKS IV, V dan VI, 3) menyusun soal tes II beserta jawabannya, 4) menyiapkan alat peraga, 5) menyusun format observasi.

b. Pelaksanaan

Pelaksanaan pada siklus II tidak jauh berbeda dengan pelaksanaan pada siklus I. Pembagian tugas tim pengajar pun sama, dengan materi yang sama. Perbedaan antara siklus I dan siklus II terletak pada pembuatan LKS dengan permasalahan yang berbeda tetapi masih satu sub pokok bahasan yang sama. Dalam pelaksanaan siklus II ini, siswa sudah beradaptasi dengan model pembelajaran team teaching, sehingga aktifitas siswa bisa meningkat. Di akhir siklus II, tim pengajar tetap melaksanakan tes II untuk mengetahui bagaiamanakah perkembangan dan pemahaman siswa dalam memahami sub pokok bahasan segitiga. Hasil tes akan di analisis pada tahap selanjutnya. Soal tes terdiri dari 10 soal obsyektif dan 5 soal essay.

c. Penilaian

1) Hasil Aktifitas Siswa Dalam Kelas pada siklus II

Berdasarkan hasil observasi yang dilakukan oleh tim pengajar selama kegiatan belajar mengajar dikelas maka dapat dilihat pada Tabel 3. 
Tabel 3. Observasi Keaktifan Siswa Siklus II

\begin{tabular}{|c|l|c|}
\hline No & \multicolumn{1}{|c|}{ Aspek Pengamatan } & Persentase \\
\hline 1 & Kemampuan siswa dalam diskusi kelompok & 89,74 \\
\hline 2 & Kemampuan siswa dalam mengemukakan pendapat & 82,77 \\
\hline 3 & $\begin{array}{l}\text { Kemampuan siswa dalam memperhatikan pemdapat } \\
\text { teman }\end{array}$ & 85,9 \\
\hline 4 & Kemampuan siswa dalam bertanya & 84,62 \\
\hline 5 & $\begin{array}{l}\text { Kemampuan siswa dalam presentasi hasil diskusi di } \\
\text { dalam kelompok }\end{array}$ & 83,33 \\
\hline 6 & $\begin{array}{l}\text { Kemampuan siswa dalam memperhatikan } \\
\text { penjelasan teman }\end{array}$ & 91,03 \\
\hline 7 & Kemampuan siswa dalam menyelesaikan LKS & 100 \\
\hline 8 & $\begin{array}{l}\text { Kemampuan siswa dalam mempresentasikan hasil } \\
\text { diskusi di depan kelas }\end{array}$ \\
\hline
\end{tabular}

Sumber: Data Primer di olah. 2018

Berdasarkan analisis hasil pengamatan, aktivitas siswa dalam mengemukakan pendapat merupakan persentase aktivitas paling rendah dibanding aktivitas lainnya. Siswa cenderung lebih banyak bertanya dibandingkan mengemukakan pendapat. Namun siswa sudah tampak terampil ketika menjelaskan materi di dalam kelompoknya.

2) Analisa Hasil belajar

Berdasarkan hasil analisis tes II diketahui bahwa terdapat 2 siswa yang tidak tuntas belajar. Sedangkan 20 siswa lainnya dinyatakan tuntas karena telah mencapai nilai minimum 70 dari skor maksimal 100 . Persentase ketuntasan hasil belajar mencapai 90,9\%. Sehingga dapat dikatakan secara klasikal pembelajaran telah mencapai ketuntasan klasikal.

e. Refleksi

Kegiatan yang dilakukan pada tahap ini adalah menganalisis, memahami dan menyimpulkan hasil pembelajaran mulai dari proses pembelajaran hingga pelaksanaan tes. Refleksi dilakukan terhadap aktifitas dan hasil belajar siswa dengan tujuan untuk mengetahui pengaruh pelaksanaan pembelajaran siklus II terhadap hasil belajar siswa. Selanjutnya hasil tersebut dibandingkan dengan hasil belajar pada siklus I.

Secara umum, proses pembelajaran berjalan dengan baik. Berdasarkan hasil pengamatan, siswa sudah tampak terbiasa dengan model pembelajaran team teaching. Siswa juga tampak lancar pada saat menjelaskan 
materi di kelompok masing-masing. Meskipun masih ada beberapa siswa yang masih membutuhkan bimbingan guru. Secara umum seluruh siswa sudah aktif dalam pembelajaran, terbukti dari prosentase aktivitas siswa yang mencapai $88,48 \%$. Sehingga dapat dikatakan bahwa aktivitas siswa pada pembelajaran siklus II termasuk kategori aktif. Dari pengamatan hasil tes, dapat diketahui bahwa konsep yang diterima siswa secara umum sudah benar. Hanya saja pada saat mengerjakan tes masih banyak siswa mengalami kendala dalam operasi hitung. Kesalahan tersebut menyebabkan siswa memperoleh hasil jawaban yang salah. Selain itu masih banyak ditemukan ketidaktelitian dalam mengerjakan tes. Prosentase ketuntasan hasil belajar siswa pada siklus II mencapai 90,90\%.

\section{E. Pembahasan}

Penerapan pembelajaran dengan model team teaching pada Sub Pokok Bahasan Segitiga kelas VIII ini bertujuan untuk mengetahui ketuntasan hasil belajar siswa. Selain itu penelitian ini juga bertujuan untuk mengetahui aktivitas siswa selama proses pembelajaran berlangsung.Pelaksanaan pembelajaran ini melibatkan dua tim pengajar, setiap anggota tim pengajar ikut berperan penuh selama proses pembelajaran berlangsung sesuai dengan tugas masing-masing yang telah disepakati bersama.

Berdasarkan hasil analisis aktivitas siswa, terjadi peningkatan dari siklus I ke siklus II. Persentase peningkatan aktivitas siswa tersebut dapat digambarkan melalui grafik berikut ini:

Gambar 5: Grafik Peningkatan Aktivitas Belajar Siswa

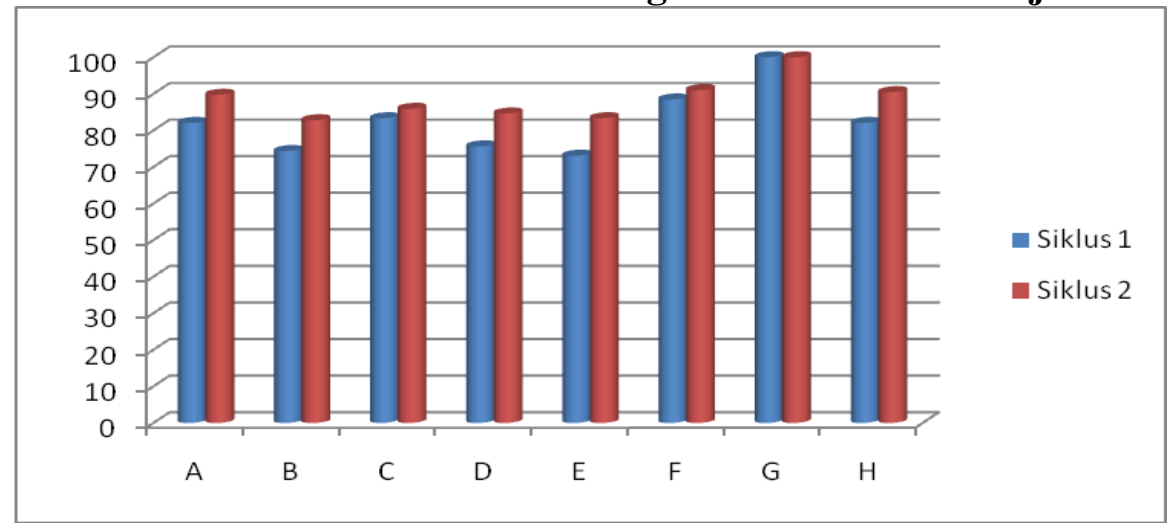

Sumber: Data Primer di olah. 2018 
Keterangan:
A : diskusi
E : presentasi hasil diskusi
B : mengemukakan pendapat
$\mathrm{F}$ :memperhatikan penjelasan
teman
C : memperhatikan pendapat teman
$\mathrm{G}$ : menyelesaikan LKS
$\mathrm{D}$ : bertanya
$\mathrm{H}$ : presentasi kelas

Pada grafik yang tersaji dapat disimpulkan bahwa setiap aktivitas siswa telah mengalami peningkatan. Meskipun untuk setiap kegiatan tidak memiliki rata-rata peningkatan yang sama. Pada saat diskusi di kelas tiap tiap kelompok masih kesulitan dalam menentukan luas dan keliling segitiga menggunakan alat peraga yang disediakan oleh tim pengajar. Meskipun masih ada kesulitan dengan menggunakan alat peraga namun siswa lebih mudah memahami ketika tim pengajar menjelaskan bagaimana menggunakan alat peraga di tiap tiap kelompok sehingga siswa dapat menarik kesimpulan dari setiap pembelajaran matematika.

Model pembelajaran team teaching dapat membantu siswa dalam memahami materi dengan baik. Sebab selain dapat belajar sendiri dengan temannya, siswa juga mendapatkan perhatian serta bimbingan secara maksimal dari guru pada saat diskusi berlangsung. Kehadiran guru sebagai fasiltator membuat guru lebih peka terhadap kendala yang dihadapi siswa sebab guru memiliki lebih banyak kesempatan dalam memantau jalannya diskusi. Sehingga siswa menerima konsep materi dengan matang dan benar. Kelebihan lain yang didapat dalam pembelajaran ini adalah suasana gaduh yang biasa terjadi selama proses pembelajaran serta pembicaraan siswa diluar materi pada saat diskusi dapat dikendalikan tim pengajar dengan baik.

Selama pelaksanaan siklus dilaksanakan, model pembelajaran team teaching dapat dikatakan cukup berhasil karena dapat meningkatkan aktivitas dan hasil belajar siswa. Terjadi peningkatan aktivitas dan hasil belajar dari pelaksanaan pembelajaran siklus I ke siklus IIsebesar 6,11\%. Jika pada siklus I aktivitas siswa $82,37 \%$ dan siklus II mencapai 88,48\%. Jadi dapat disimpulkan bahwa aktivitas siswa termasuk dalam kategori aktif.Sedangkan untuk hasil belajar siswa pada siklus I sebesar 77,27\% dan 90,9\% pada siklus 
II, sehingga hasil belajar siswa mengalami peningkatan sebesar 13,63\%. Hal ini menunjukkan bahwa model pembelajaran team teaching dapat meningkatkan aktivitas siswa serta hasil belajar siswa. Berdasarkan analisa hasil tes I dan II, salah satu kendala yang dihadapi siswa pada saat mengerjakan tes adalah kurangnya pemahaman siswa terhadap operasi hitung. Faktor lainnya adalah ketidaktelitian siswa dalam mengerjakan tes yang diberikan.

\section{F. Kesimpulan}

Ada beberapa kesimpulan yang dapat diambil berdasarkan hasil dan pembahasan, yaitu:

1. Implementasi model pembelajaran team teachingsecara umum berjalan dengan lancar. Hanya saja keterbatasan waktu menjadi salah satu kendala dalam pelaksanaan pembelajaran. Pengelolahan pembelajaran dan bimbingan dilakukan bersama-sama dan adil. Secara bergantian pada setiap pertemuan, satu guru bertindak sebagai penyaji sedangkan guru lain bertugas membantu.

2. Aktitivitas siswa pada model pembelajaran team teaching pada siklus I sebesar $82,37 \%$ mengalami peningkatan pada siklus II sebesar $88,48 \%$.

3. Ketuntasan hasil belajar siswa pada model pembelajaran team teaching pada siklus I sebesar 77,27\% meningkat pada siklus II menjadi 90,9\%. Pada siklus I, ada 5 siswa yang nilainya dibawah KKM, pada siklus II, masih ada 2 siswa yang nilainya dibawah KKM.

Berdasarkan hasil penelitian ini, saran yang dapat diberikan peneliti kepada peneliti lain yaitu:

1. Peneliti lain dapat meneliti lebih lanjut tentang model pembelajaran team teaching materi segitiga untuk populasi yang lebih besar lagi.

2. Peneliti lain dapat mengembangkan model pembelajaran team teaching untuk materi matematika yang lainnya. 


\section{Daftar Pustaka}

Arikunto, S, dkk. 2008. Penelitian Tindakan Kelas. Jakarta: Bumi Aksara.

Awie, AH. 2010. Team Teaching Sebagai Implementasi Penerapan Lesson Study (serial online). http://lensakomunika.blogspot.com/2010/02/team-teachingsebagai-imple-mentasi.htlm.Diaskes pada tanggal 13 Februari 2018.

Djamarah dan Zain. 2002. Strategi Belajar Mengajar. Jakarta: PT Rineka Cipta. Engkoswara. 1988. Dasar-Dasar Metodologi Pengajaran. Jakarta : Bina Aksara. Hamalik, O. 2009. Proses Belajar Mengajar. Jakarta: PT Bumi Aksara

Nuharini D, dan Wahyuni, T. 2008. Matematika Konsep dan Aplikasinya. Jakarta: Depdiknas.

Riyanto, M. 2008. Paradigma Pembelajaran. Surabaya: Unesa University Press.

Wardani, Igak. 2001.Team Teaching. Jakarta: Departemen Pendidikan Nasional, hal. 5

Wardhani, S. 2009. Analisis SI Dan SKL Mata Pelajaran Matematika SMP/ MTs Untuk Mengoptimalisasi Pencapaian Tujuan. Yogyakarta: Pusat Pengembangan Dan Pemberdayaan Pendidik Dan Tenaga Pendidik. 